\title{
Identification of Substances Produced by Cercospora brachiata in Absence of Light and Evaluation of Antibacterial Activity
}

\author{
John K. R. P. Felisbino ${ }^{1}$, Bruno S. Vieira ${ }^{2}{ }^{\circledR}$, Alberto de Oliveira ${ }^{1}\left(\mathbb{D}\right.$, Neiliane A. da Silva $^{2}$, \\ Carlos H. G. Martins ${ }^{3}{ }^{(D}$, Mariana B. Santiago ${ }^{3} \mathbb{D}$, Rodrigo A. A. Munoz ${ }^{1} \mathbb{D}$, Luís C. S. Cunha ${ }^{4}$ and \\ Raquel M. F. Sousa $1, * \mathbb{D}$ \\ 1 Instituto de Química, Universidade Federal de Uberlândia, Uberlândia 38400-902, Brazil; \\ johnkenedy7@hotmail.com (J.K.R.P.F.); alberto@ufu.br (A.d.O.); munoz@ufu.br (R.A.A.M.) \\ 2 Instituto de Ciências Agrárias, Universidade Federal de Uberlândia, Monte Carmelo 38500-000, Brazil; \\ brunovieira@ufu.br (B.S.V.); nena.a@hotmail.com (N.A.d.S.) \\ 3 Instituto de Ciências Biomédicas, Universidade Federal de Uberlândia, Uberlândia 38400-902, Brazil; \\ carlos.martins2@ufu.br (C.H.G.M.); mari.brentini@hotmail.com (M.B.S.) \\ 4 Departamento de Química, Instituto Federal do Triangulo Mineiro, Uberaba 38064-100, Brazil; \\ luisscunha@gmail.com \\ * Correspondence: rsousa@ufu.br; Tel.: +55-3432394143
}

Citation: Felisbino, J.K.R.P.; Vieira, B.S.; de Oliveira, A.; da Silva, N.A.; Martins, C.H.G.; Santiago, M.B.; Munoz, R.A.A.; Cunha, L.C.S.; Sousa, R.M.F. Identification of Substances Produced by Cercospora brachiata in Absence of Light and Evaluation of Antibacterial Activity. J. Fungi 2021, 7, 680. https://doi.org/10.3390/ jof7090680

Academic Editors: Jasmina Glamočlija and Dejan Stojković

Received: 31 July 2021

Accepted: 19 August 2021

Published: 24 August 2021

Publisher's Note: MDPI stays neutral with regard to jurisdictional claims in published maps and institutional affiliations.

Copyright: (c) 2021 by the authors. Licensee MDPI, Basel, Switzerland. This article is an open access article distributed under the terms and conditions of the Creative Commons Attribution (CC BY) license (https:// creativecommons.org/licenses/by/ $4.0 /)$.
Abstract: Cercospora brachiata is a phytopathogenic fungus. To know more about the metabolites produced by this fungus, the objective of this work was to identify, isolate and characterize substances present in extracts of the growth broth and mycelium, using gas chromatography with mass spectrometry (GC-MS) and nuclear magnetic resonance (NMR). It was also objective to evaluate the antibacterial activity of the extracts. Among the compounds identified, fatty acids, esters, and steroids can be highlighted. The main compounds identified are 9-hexadecenoic, hexadecenoic, oleic, octadecanoic, lauric, myristic, palmitic, doceno-13-enoic, stearic, linoleic, and nonadecanoic acids present in almost all extracts. For the antibacterial activity, the broth microdilution method was used. The ethyl acetate extract of the mycelium presented inhibitory concentrations (MICs) against the bacterium Actinomyces naeslundii $\left(100 \mu \mathrm{g} \mathrm{mL}^{-1}\right)$ and Streptococcus sanguinis $\left(200 \mu \mathrm{g} \mathrm{mL}^{-1}\right)$. Finally, two steroids were isolated and identified in the hexane extract of mycelium: ergosta-6,22-dien- $3 \beta, 5 \alpha, 8 \alpha$-triol and brassicasterol.

Keywords: Cercospora brachiata; secondary metabolites; antibacterial activity; fungus; oral bacteria

\section{Introduction}

Fungi can be classified according to the type of host. Fungi that use host plants are called endophytic plants which do not cause plant diseases, while phytopathogens cause many types of diseases in theirs hosts [1], which is the case of some Cercospora species [2].

Phytopathogenic fungi can produce toxic substances. The toxins, therefore, are secondary metabolites produced by fungi, usually of low molecular mass (<1000 Da), that may be related to the infection process in their hosts [3].

Some fungi are also harmful to plants for being necrotrophic causing plant cells death during plant tissue colonization. One of the genera of necrothophic fungi is Cercospora, which produces toxins such as cercosporin involved in the pathogenicity of these fungi, that can be activated by light $[4,5]$, causing lesions in leaves, stems, and fruits. One of the plants parasitized by one species of Cercospora, known as Cercospora coffeicola, is coffee, whose productivity can be reduced by up to $30 \%$ for this pathogen [6,7].

Fungi may also produce compounds capable of preventing the growth of bacteria. This activity is associated with the fact that fungi produce secondary metabolites capable of inhibiting the action of bacteria and even of other fungi, as in the case of extracts from cultures of Cercospora spp. isolates [8]. Bacteria used to test the antibacterial activity herein 
reported belonging to gram-positive and gram-negative types of the oral cavity. For Kumar (2013), there are more than 1000 species of bacteria in the oral cavity of a human being, and these bacteria are displaced to other parts of the body causing other diseases such as inflammation of the prostate, asthma, pneumonia, endocarditis, diabetes, etc. [9]. Thus, it is necessary to investigate and use new compounds that are capable of inhibiting the growth of these bacteria.

Thus, the objective of this work was to identify the substances present in extracts of the growth broth and mycelium extract of the fungus Cercospora brachiata, a foliar pathogen of Amaranthus viridis, and also to test the antibacterial activity of these extracts against aerobic and anaerobic bacteria of the human oral cavity.

\section{Materials and Methods}

\subsection{Chemicals and Reagents}

The following standard analytical solvents were used: hexane (Neon ${ }^{\circledR}$, São Paulo, SP, Brazil), ethyl acetate (Panreac ApliChem ITW Companies ${ }^{\circledR}$, Darmstadt, Germany), ethanol (Synth $^{\circledR}$, Diadema, Brazil), dichloromethane (Vetec Fine Chemical ${ }^{\circledR}$, Rio de Janeiro, RJ, Brazil), methanol (Sigma-Aldrich ${ }^{\circledR}$, San Luis, Missouri, EUA), and deuterated chloroform $\left(\right.$ Sigma-Aldrich $\left.{ }^{\circledR}\right)$.

\subsection{Instrumentation}

The composition of extracts and isolated compounds were identified by a gas chromatograph coupled to a mass spectrometer (Shimadzu, QP2010) using a DB-5 capillary column $(\mathrm{J} \& W, 30 \mathrm{~m} \times 0.25 \mathrm{~mm} \times 0.25 \mathrm{~m})$. The conditions used were: helium as a carrier gas with a constant flow of $1.0 \mathrm{~mL} \mathrm{~min}^{-1}$; injector temperature of $220^{\circ} \mathrm{C}$, split 1:20; the temperature of the oven increased from 60 to $246{ }^{\circ} \mathrm{C}$ at $3{ }^{\circ} \mathrm{C} \mathrm{min}$ min $^{-1}$ and maintained for $24 \mathrm{~min}$ at $246{ }^{\circ} \mathrm{C}$; the ionizing potential of $70 \mathrm{eV}$; the range of $\mathrm{m} / \mathrm{z}$ from 40 to 650 . The identification of the compounds by this technique was based on the arithmetic index (AI) calculated and compared to that of Adams (2007) [10]. The similarity index (IS) obtained by the software (LabSolution-GCMS Solution) was also used by comparison with spectra present in the Nist27 libraries, Nist147, Wiley7, Wiley229, and Shim2205. The NMR analyses of ${ }^{1} \mathrm{H}$ and ${ }^{13} \mathrm{C}$ were carried out using a Bruker (AscendTM 400 Avance III HD model) equipment with 9.4 Tesla and $400 \mathrm{MHz}$.

\subsection{Fungal Culture}

Isolation and identification of the fungus C. brachiata were carried out at the Institute of Agricultural Sciences of the Federal University of Uberlândia (Monte Carmelo, MG-Brazil) by Dr. Bruno S. Vieira and collaborators [11], who reported this fungus for the first time in Brazil. The fungus was isolated from infected leaves of Amaranthus viridis L. (Caruru, voucher specimen VIC 47,138 deposited in the Herbarium at the Federal University of Viçosa, MG-Brazil). The fungus was grown in Petri dishes containing the potato-dextroseagar medium (PDA) at $25^{\circ} \mathrm{C}$ for 7 days. Mycelium discs $(\varnothing=10 \mathrm{~mm})$ from the periphery of actively growing cultures were aseptically transferred to erlenmeyer containing $250 \mathrm{~mL}$ of the modified Jenkins-Prior liquid culture medium [12]. The erlenmeyers flasks were transferred to an orbital shaker at $150 \mathrm{rpm}$ in the dark at $25^{\circ} \mathrm{C}$ for 21 days. The cultures obtained were filtered using Buchner's vacuum funnel to separate the mycelium from the growth broth [13].

\subsection{Isolation and Purification of Compounds}

Extract of growth broth from $5 \mathrm{~L}$ of $\mathrm{C}$. brachiata was prepared by liquid-liquid partition using ethyl acetate $(5 \times 200 \mathrm{~mL})$ at $\mathrm{pH}$. After removal of solvent, $0.505 \mathrm{~g}$ of extract was obtained.

Extract of mycelia from $174 \mathrm{~g}$ of C. brachiata was prepared by maceration using methanol $(600 \mathrm{~mL})$ for 5 days at room temperature [14]. After removal of solvent, $100 \mathrm{~mL}$ of distilled water was added to the crude extract in a decantation flask and the liquid-liquid 
fraction was made using hexane $(3 \times 200 \mathrm{~mL})$ and ethyl acetate $(3 \times 200 \mathrm{~mL})$. After removal of solvent, $1.33 \mathrm{~g}$ of extract in hexane and $0.122 \mathrm{~g}$ of extract in ethyl acetate were obtained.

The hexane fraction of the mycelium was used for chromatography. Silica $60 \mathrm{G}$ of 40-270 mesh was used as the stationary phase and ethyl acetate/hexane as mobile gradient phase, starting at a ratio of 1:4. From the first column, 24 fractions were obtained, of which fraction 8 was analyzed in NMR, and ergosta-6,22-dien-3 $\beta, 5 \alpha, 8 \alpha$-triol was identified. The fractions 3 to 7 were pooled to make the second column. From this column, three fractions were obtained, and the compounds from fraction 1 were separated in the third column. From this column, four fractions were obtained, and fraction 3 was analyzed in NMR, and brassicasterol was identified. NMR spectra are presented as supplementary files (Figures S1-S7).

\subsection{Antibacterial Activity}

Biological assays to verify antimicrobial activity were performed by determining MIC (minimum inhibition concentration). The oral bacteria were obtained from the American Type Culture Collection (ATCC, Rockville, MD, USA). The following aerobic bacteria were used: Streptococcus mutans (ATCC 25175), S. mitis (ATCC 49456), S. sanguinis (ATCC 10556), Aggregatibacter actinomycetemcomitans (ATCC 43717). The following anaerobic bacteria were used: Porphyromonas gingivalis (ATCC 33277), Fusobacterium nucleatum (ATCC 25586) and Actinomyces naeslundii (ATCC 19039). The analysis of the antibacterial activity was performed in microplates containing 96 wells. The inoculum, the broth, and the sample were added to each well, yielding a final volume of $100 \mu \mathrm{L}$ for aerobic bacteria and $200 \mu \mathrm{L}$ for anaerobic bacteria. The volume of inoculum added in the microplate wells was $20 \mu \mathrm{L}$ for the aerobic bacteria tests and $40 \mu \mathrm{L}$ for the anaerobic bacteria tests. The concentrations of the samples tested against aerobic and anaerobic bacteria were from $0.195 \mu \mathrm{g} \mathrm{mL} \mathrm{m}^{-1}$ to $400 \mu \mathrm{g} \mathrm{mL}^{-1}$. Chlorhexidine $\left(0.115\right.$ to $\left.59.0 \mu \mathrm{g} \mathrm{mL}^{-1}\right)$ was used as positive control for aerobic and anaerobic bacteria. To control the technique, metronidazole (0.0115 to $5.9 \mu \mathrm{g} \mathrm{mL}^{-1}$ ) was used as control for anaerobic bacteria against Bacteroides fragilis and B. thetaiotaomicron. Dimethylsulfoxide (DMSO) (5.0 to 1.0\%, v/v concentration) was used as the solvent control. Sterility controls of the positive control, culture medium, and samples were also performed.

For aerobic bacteria, the microplates were incubated in microaerophilia by the flame/candle system at $37{ }^{\circ} \mathrm{C}$ for $24 \mathrm{~h}$. After the incubation period, $30.0 \mu \mathrm{L}$ of the resazurin indicator $(0.02 \% \mathrm{~m} / \mathrm{v})$ was added to each well [15]. For anaerobic bacteria were incubated for $72 \mathrm{~h}$ in an anaerobic chamber (atmosphere containing: $5-10 \% \mathrm{H}_{2}, 10 \% \mathrm{CO}_{2}$, $80-85 \% \mathrm{~N}_{2}$ ) at $36{ }^{\circ} \mathrm{C}$ and revealed with the same indicator [16].

\section{Results and Discussion}

\subsection{Compounds Identified by GC-MS}

Some compounds identified by GC-MS can be highlighted because they are common among the extracts of the analyzed fungi, such as long-chain fatty acids (9-hexadecenoic, hexadecanoic, oleic, octadecanoic, lauric, myristic, palmitic, docos-13-enoic, stearic, linoleic, and nonadecanoic acids) $[17,18]$.

Fatty acids play important cellular roles in biological systems. This is because these molecules make up the constitution of the cell walls, regulate the activity of enzymes and inflammatory processes [19]. Fatty acids are long-chain carboxylic acids (hydrocarbons) and are the components of many lipids, including glycerides. As they are one of the building blocks used in the production of complex lipids, they have considerable medicinal and nutritional value. For example, gamma linolenic acid (GLA, an omega- 6 fatty acid) in the form of evening primrose oil (EPO) has been used to treat rheumatoid arthritis, multiple sclerosis, schizophrenia, and premenstrual syndrome. Eicosapentaenoic acid acetic acid (EPA) and docosahexaenoic acid (DHA, both omega-3 fatty acids) have physiological effects in areas such as heart, circulation, inflammation, and cancer [20]. 
According to Blacklock et al. [21], there is a diversity in the synthesis of fungal fatty acids, and their identification by GC-MS can be facilitated when they are esterified, for example, methyl hexadecanoate, (Z) -9-octadecenoate, methyl octadecenoate, methyl palmitate, methyl oleate, and methyl linoleate esters were identified in fungal extracts.

Other compounds identified were steroids, which are substances found in almost every living organism, whether in plants, fungi, bacteria, or in human beings. According to Dewick [22], steroids are modified triterpenoids and their biosynthesis is the route of mevalonic acid (MVA), which is formed by three molecules of acetyl-CoA.

Table 1 shows the compounds identified by GC-MS in the ethyl acetate extract of the fungus growth broth and the extracts in hexane and ethyl acetate from the mycelium of the fungus. The structures of the identified compounds are shown in Figure 1.

Table 1. Compounds identified by GC-MS of C. brachiata extracts.

\begin{tabular}{|c|c|c|c|c|c|c|c|c|}
\hline & Compounds & Sample * & TR (min) & TIC (\%) & $\begin{array}{c}\text { AI } \\
\text { Observed }\end{array}$ & AI Literature ** & Library & SI \\
\hline 1 & $\begin{array}{c}\text { 1,4-diaza-2,5-dioxo-3- } \\
\text { isobutylbicyclo-[4.3.0]-nonane }\end{array}$ & $\mathrm{B} / \mathrm{A}$ & 42.4 & $23.31 / 12.71$ & - & - & WILEY7 & $92 / 91$ \\
\hline 2 & Hexadecanoic acid, methyl ester & A & 43.2 & 5.88 & 1935 & 1933 & NIST27 & 93 \\
\hline 3 & Linoleic acid, methyl ester & $\mathrm{B} / \mathrm{A}$ & 48.4 & $4.95 / 8.09$ & 2101 & 2092 & WILEY7 & $96 / 94$ \\
\hline 4 & $\begin{array}{l}\text { 10-octadecenoic acid, } \\
\text { methyl ester }\end{array}$ & A & 48.6 & 8.44 & 2108 & 2110 & WILEY229 & 95 \\
\hline 5 & $\begin{array}{l}\text { Octadecanoic acid, methyl ester } \\
\text { Ergotaman- } 3^{\prime}, 6^{\prime}, 18 \text {-trione, }\end{array}$ & A & 49.5 & 1.53 & 2138 & 2135 & WILEY7 & 90 \\
\hline 6 & $\begin{array}{l}\text { 9,10-dihydro-12 } \\
\text { '-hydroxy-2'-methyl-5'- } \\
\text { (phenylmethyl)-,(5',10a) }\end{array}$ & $\mathrm{B} / \mathrm{A}$ & 56.1 & $6.21 / 3.18$ & - & - & NIST27 & $86 / 87$ \\
\hline 7 & Mevalonic lactone & $\mathrm{B}$ & 17.7 & 1.52 & 1260 & - & & 92 \\
\hline 8 & Isonicotinamide & $\mathrm{B}$ & 23.5 & 1.66 & 1408 & 1426 & WILEY7 & 92 \\
\hline 9 & Cycloalanylleucine & B & 36.2 & 4.61 & - & - & WILEY7 & 92 \\
\hline 10 & Hexadecanoate, methyl ester & $\mathrm{B} / \mathrm{C}$ & 43.2 & $4.12 / 5.88$ & 1935 & 1926 & NIST27 & $96 / 96$ \\
\hline 11 & Palmitic acid & B & 44.4 & 3.12 & 1971 & 1975 & NIST27 & 94 \\
\hline 12 & Oleic acid, methyl ester & $\mathrm{B}$ & 48.7 & 4.92 & 2111 & 2103 & WILEY7 & 95 \\
\hline 13 & Octadecanoic acid, methyl ester & B & 49.5 & 1.14 & 2138 & 2138 & WILEY229 & $91 / 96$ \\
\hline 14 & Linoleic acid & $\mathrm{B} / \mathrm{C}$ & 49.7 & $2.61 / 38.13$ & 2145 & 2132 & WILEY7 & $91 / 91$ \\
\hline 15 & Oleic acid & $\mathrm{B} / \mathrm{C}$ & 49.9 & $6.85 / 6.26$ & 2151 & 2141 & WILEY7 & $86 / 92$ \\
\hline 16 & Linoleic acid, ethyl ester & B & 50.5 & 0.61 & 2169 & 2163 & NIST27 & 84 \\
\hline 17 & Brassicasterol & $\mathrm{B} / \mathrm{C}$ & 88.4 & $3.45 / 3.58$ & - & - & WILEY7 & $75 / 81$ \\
\hline 18 & $\begin{array}{l}\text { Octadeca-9,12-dienonoic acid, } \\
\text { methyl ester }\end{array}$ & $\mathrm{C}$ & 48.8 & 19.52 & 1862 & - & WILEY7 & 97 \\
\hline 19 & $\begin{array}{c}\text { (E) -9-Octadecenonoic acid, } \\
\text { methyl ester }\end{array}$ & $\mathrm{C}$ & 49.0 & 12.05 & 2122 & 2110 & NIST27 & 96 \\
\hline 20 & Stearic acid & $\mathrm{C}$ & 51.2 & 2.05 & 2196 & 2188 & NIST27 & 92 \\
\hline 21 & $\begin{array}{l}\text { Hexahydro-4,4,7a-trimethyl-2- } \\
\text { benzofuranone }\end{array}$ & C & 54.2 & 0.17 & 2303 & 2305 & WILEY229 & 80 \\
\hline 22 & $\begin{array}{l}\text { 11,14-Eicosadienonoic acid, } \\
\text { methyl ester }\end{array}$ & C & 54.5 & 0.08 & 2313 & - & WILEY7 & 96 \\
\hline 23 & $\begin{array}{c}\text { Eicosanonoic acid, methyl ester } \\
\qquad N, N, N^{\prime},\end{array}$ & $\mathrm{C}$ & 55.4 & 0.21 & 2374 & 2339 & WILEY7 & 95 \\
\hline 24 & $\begin{array}{c}N^{\prime} \text {-Tetramethyl-2,2'-oxybis } \\
\text { (ethylamine) }\end{array}$ & $\mathrm{C}$ & 58.8 & 0.30 & 2475 & - & NIST27 & 92 \\
\hline 25 & Docosanonoic acid, methyl ester & $\mathrm{C}$ & 60.7 & 0.04 & 2547 & 2530 & NIST27 & 94 \\
\hline 26 & $\begin{array}{l}\text { Cholesta-8,24-dien-3-ol, } \\
\text { 4-methyl-, }(3 \beta, 4 \alpha)\end{array}$ & $\mathrm{C}$ & 61.9 & 0.06 & 2597 & - & WILEY229 & 78 \\
\hline 27 & Tetracosanoic acid, methyl ester & $\mathrm{C}$ & 66.4 & 0.16 & 2739 & 2731 & WILEY7 & 95 \\
\hline 28 & $\begin{array}{c}\text { Ergosta-5,7-dien-3-ol, }(3 \beta) \\
\text { (22E)-Ergosta- }\end{array}$ & $\mathrm{C}$ & 75.8 & 0.73 & 2948 & - & WILEY7 & 60 \\
\hline 29 & $\begin{array}{l}\text { 5,7,9(11),22-tetraen-3-yl } \\
\text { 3,5-dinitrobenzoate }\end{array}$ & $\mathrm{C}$ & 77.4 & 0.25 & 2980 & - & NIST27 & 71 \\
\hline 30 & Ergosta-7,22-dien-3-ol, $(3 \beta, 22 \mathrm{E})$ & $\mathrm{C}$ & 93.9 & 0.57 & - & - & WILEY229 & 80 \\
\hline
\end{tabular}

Note: * A: ethyl acetate from the growth broth; B: ethyl acetate from mycelia; C: hexane from mycelia. ${ }^{* *}$ Adams (2007) [10].

\subsection{Isolated Compounds}

The hexane fraction was fractionated through column chromatography. Fraction 8 from the first column and fraction 3 from the third column were analyzed by NMR and the compounds ergosta-6,22-dien- $3 \beta, 5 \alpha, 8 \alpha$-triol (31), and brassicasterol (17) were characterized, respectively (Figure S1).

Ergosta-6,22-dien-3 $3,5 \alpha, 8 \alpha$-triol (31) from fraction 8 of first column 3 was analyzed by the ${ }^{13} \mathrm{C}-\mathrm{NMR}$ and 28 carbons were found in the spectrum, which matched the possible structures of the Ergosta-like molecules identified by GC-MS at retention times 75.8 to 93.9 min, with respective similarity indexes of 60 and 80, shown in Table 1. Compound 31 
was not identified by GC-MS, probably because the presence of three hydroxyl groups results in a compound not volatile enough to be analyzed in the conditions used in this analysis.

Of the 28 signals observed in the ${ }^{13} \mathrm{C}-\mathrm{NMR}$ spectrum (Figure S6) of compound 31, 3 signals were in the region of carbinolic carbons, 867.1 (C-3), 82.7 (C-5) and 79.9 ppm (C-8); 4 signals were in the carbons methynic group at $\delta 136.0$ (C-6), 131.3 (C-7), 132.8 (C-22), and $135.7 \mathrm{ppm}(\mathrm{C}-23)$.

From DEPT-135 (Figure S7) it was possible to verify the absence of carbons 10 and 13 which are quaternary, with displacements in $\delta 37.5$ and $45.1 \mathrm{ppm}$, respectively. It was also verified that the carbons 5 and 8 are not quaternary, but they do not present hydrogens, therefore, do not appear in DEPT-135. Additionally, the presence of 6 carbons from methylic group in 813.4 (C-18), 18.7 (C-19), 18.1 (C-21), 20.5 (C-26), 20.2 (C-27), and 21.4 ppm (C-28).

The DEPT-135 also allowed the identification of methylene carbons, with displacements in $\delta 35.2$ (C-1), 39.8 (C-2), 37.4 (C-4) 21.2 (C-11), 30.6 (C-12), 23.9 (C-15), and $29.2 \mathrm{ppm}(\mathrm{C}-16)$, and the methyl carbons at 52.2 (C-9), 56.7 (C-14), 33.6 (C-17), 43.3 (C-20), 40.2 (C-24), and $51.6 \mathrm{ppm}(\mathrm{C}-25)$. The data obtained by the ${ }^{13} \mathrm{C}-\mathrm{NMR}$ were compared with data from Rivera, Benavides, and Rios [23] (Table 2), which confirmed the structure of Ergosta-6,22-dien-3 $\beta, 5 \alpha, 8 \alpha$-triol (31).

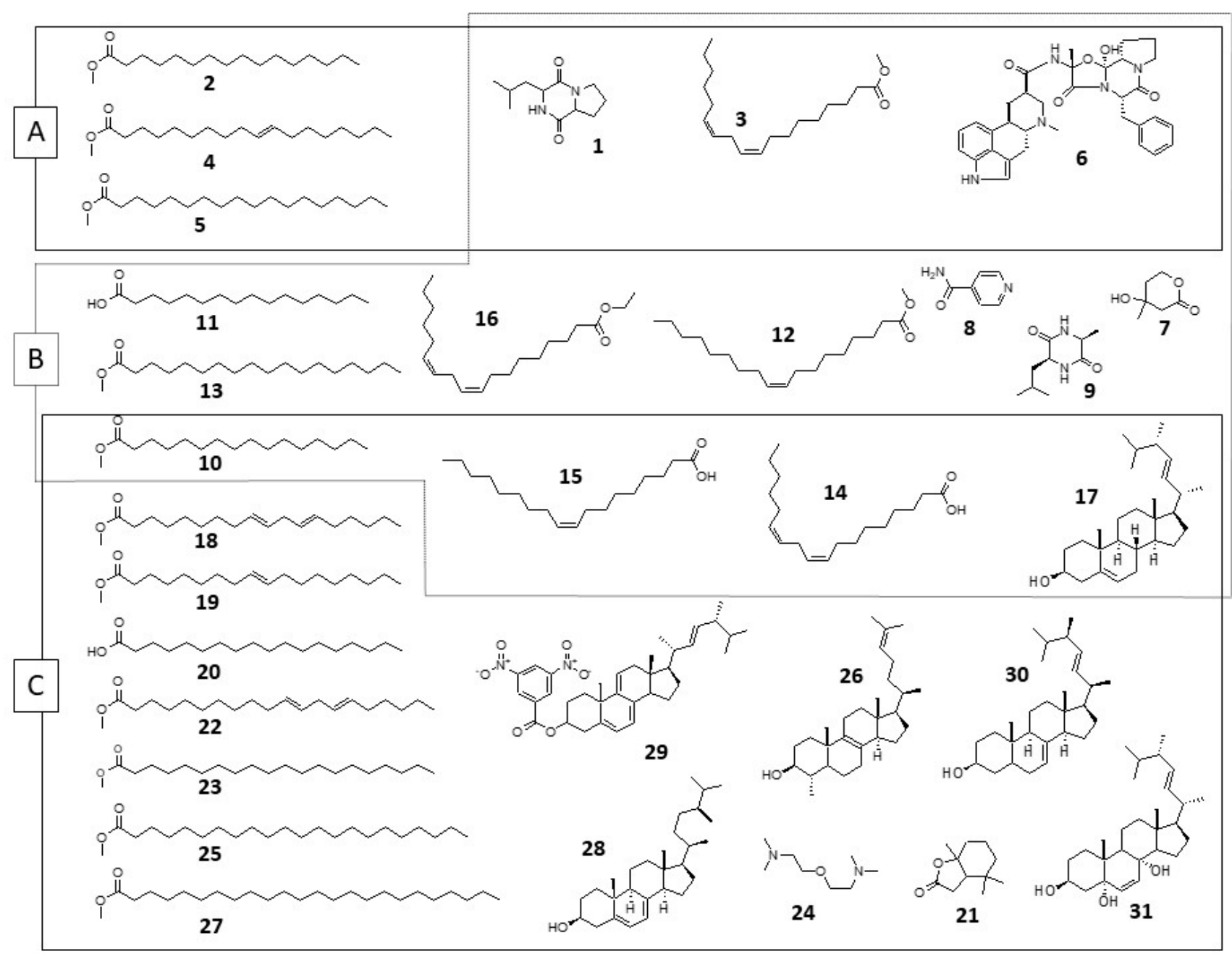

Figure 1. Structures of the compounds identified in C. brachiata extracts. (A): ethyl acetate from the growth broth; (B): ethyl acetate from mycelium; (C): hexane from mycelium. 
Table 2. ${ }^{1} \mathrm{H}$ and ${ }^{13} \mathrm{C}$ NMR data of ergosta-6,22-dien-3 $\beta, 5 \alpha, 8 \alpha$-triol (31).

\begin{tabular}{|c|c|c|c|c|c|}
\hline \multirow[b]{2}{*}{ Carbon } & \multicolumn{3}{|c|}{ Experimental Data } & \multicolumn{2}{|c|}{ Literature [23] } \\
\hline & $\begin{array}{c}{ }^{1} \mathrm{H} \mathrm{NMR} \\
\left(400 \mathrm{MHz} \mathrm{CDCl}_{3}\right) \\
\delta(\mathrm{m}, \text { Integral}, J)\end{array}$ & $\begin{array}{c}{ }^{13} \mathrm{C} \mathrm{NMR} \\
\left(100 \mathrm{MHz}, \mathrm{CDCl}_{3}\right) \\
\delta\end{array}$ & DEPT-135 & $\begin{array}{c}{ }^{1} \mathrm{H} \text { NMR } \\
\left(400 \mathrm{MHz} \mathrm{CDCl}_{3}\right) \\
\delta(\mathrm{m}, \text { Integral, } J)\end{array}$ & $\begin{array}{c}{ }^{13} \mathrm{C} \mathrm{NMR} \\
\left(100 \mathrm{MHz}, \mathrm{CDCl}_{3}\right) \\
\delta\end{array}$ \\
\hline 1 & $1.20-2.1(\mathrm{~m}, 2 \mathrm{H})$ & 35.2 & $\mathrm{CH}_{2}$ & $\begin{array}{l}1.96(\mathrm{~m}, 1 \mathrm{H} \alpha) \\
1.69(\mathrm{~m}, 1 \mathrm{H} \beta)\end{array}$ & 34.7 \\
\hline 2 & $1.20-2.1(\mathrm{~m}, 2 \mathrm{H})$ & 39.8 & $\mathrm{CH}_{2}$ & $\begin{array}{l}1.99(\mathrm{~m}, 1 \mathrm{H} \beta) \\
1.24(\mathrm{~m}, 1 \mathrm{H} \alpha)\end{array}$ & 39.2 \\
\hline 3 & & 67.1 & $\mathrm{CH}$ & & 66.5 \\
\hline 4 & $1.20-2.1(\mathrm{~m}, 2 \mathrm{H})$ & 37.4 & $\mathrm{CH}_{2}$ & 2.11 e $1.92(\mathrm{~m}, 2 \mathrm{H})$ & 36.9 \\
\hline 5 & & 82.7 & $\mathrm{C}^{2}$ & & 82.2 \\
\hline 6 & $6.5(\mathrm{~d}, 1 \mathrm{H}, 8.3 \mathrm{~Hz})$ & 136.0 & $\mathrm{CH}$ & $6.6(\mathrm{~d}, 1 \mathrm{H}, 8.5 \mathrm{~Hz})$ & 135.4 \\
\hline 7 & $6.3(\mathrm{~d}, 1 \mathrm{H}, 8.3 \mathrm{~Hz})$ & 131.3 & $\mathrm{CH}$ & $6.33(\mathrm{~d}, 1 \mathrm{H}, 8.5 \mathrm{~Hz})$ & 130.7 \\
\hline 8 & & 79.9 & $\mathrm{C}$ & & 79.4 \\
\hline 9 & $1.20-2.1(\mathrm{~m}, 1 \mathrm{H})$ & 52.2 & $\mathrm{CH}$ & $1.59(\mathrm{~m}, 1 \mathrm{H})$ & 21.7 \\
\hline 10 & & 37.5 & $\mathrm{C}$ & & 37.0 \\
\hline 11 & $1.20-2.1(\mathrm{~m}, 2 \mathrm{H})$ & 21.2 & $\mathrm{CH}_{2}$ & $1.62(\mathrm{~m}, 2 \mathrm{H})$ & 20.6 \\
\hline 12 & $1.20-2.1(\mathrm{~m}, 2 \mathrm{H})$ & 30.6 & $\mathrm{CH}_{2}$ & 1.82 and $1.55(\mathrm{~m}, 2 \mathrm{H})$ & 30.1 \\
\hline 13 & & 45.1 & $\mathrm{C}^{2}$ & & 44.6 \\
\hline 14 & $1.20-2.1(\mathrm{~m}, 1 \mathrm{H})$ & 56.7 & $\mathrm{CH}$ & $1.19(\mathrm{~m}, 1 \mathrm{H})$ & 56.2 \\
\hline 15 & $1.20-2.1(\mathrm{~m}, 2 \mathrm{H})$ & 23.9 & $\mathrm{CH}_{2}$ & $1.22(\mathrm{~m}, 2 \mathrm{H})$ & 23.4 \\
\hline 16 & $1.20-2.1(\mathrm{~m}, 2 \mathrm{H})$ & 29.2 & $\mathrm{CH}_{2}$ & $1.33(\mathrm{~m}, 2 \mathrm{H})$ & 28.6 \\
\hline 17 & & 33.6 & $\mathrm{CH}$ & & 33.1 \\
\hline 18 & $0.82(\mathrm{~s}, 3 \mathrm{H})$ & 13.4 & $\mathrm{CH}_{3}$ & $0.82(\mathrm{~s}, 3 \mathrm{H})$ & 12.9 \\
\hline 19 & $0.88(\mathrm{~s}, 3 \mathrm{H})$ & 18.7 & $\mathrm{CH}_{3}$ & $0.89(\mathrm{~s}, 3 \mathrm{H})$ & 18.2 \\
\hline 20 & $1.20-2.1(\mathrm{~m}, 1 \mathrm{H})$ & 43.3 & $\mathrm{CH}$ & $1.82(\mathrm{~m}, 1 \mathrm{H})$ & 42.8 \\
\hline 21 & $0.90(\mathrm{~d}, 3 \mathrm{H}, 6.5 \mathrm{~Hz})$ & 18.1 & $\mathrm{CH}_{3}$ & $0.92(\mathrm{~d}, 3 \mathrm{H}, 6.3 \mathrm{~Hz})$ & 17.6 \\
\hline 22 & $5.1-5.2(\mathrm{~m}, 1 \mathrm{H})$ & 132.8 & $\mathrm{CH}$ & $5.18(\mathrm{~m}, 1 \mathrm{H})$ & 132.3 \\
\hline 23 & $5.1-5.2(\mathrm{~m}, 1 \mathrm{H})$ & 135.7 & $\mathrm{CH}$ & $5.22(\mathrm{~m}, 1 \mathrm{H})$ & 135.2 \\
\hline 24 & $1.20-2.1(\mathrm{~m}, 1 \mathrm{H})$ & 40.2 & $\mathrm{CH}$ & $2.02(\mathrm{~m}, 1 \mathrm{H})$ & 39.7 \\
\hline 25 & $1.20-2.1(\mathrm{~m}, 1 \mathrm{H})$ & 51.6 & $\mathrm{CH}$ & $1.48(\mathrm{~m}, 1 \mathrm{H})$ & 51.1 \\
\hline 26 & $0.80-0.84(\mathrm{~m}, 3 \mathrm{H})$ & 20.5 & $\mathrm{CH}_{3}$ & $0.85(\mathrm{~d}, 3 \mathrm{H}, 6.6 \mathrm{~Hz})$ & 19.9 \\
\hline 27 & $0.80-0.84(\mathrm{~m}, 3 \mathrm{H})$ & 20.2 & $\mathrm{CH}_{3}$ & $0.81(\mathrm{~d}, 3 \mathrm{H}, 6.6 \mathrm{~Hz})$ & 19.6 \\
\hline 28 & $1.0(\mathrm{~d}, 3 \mathrm{H}, 6.7 \mathrm{~Hz})$ & 21.4 & $\mathrm{CH}_{3}$ & $1.01(\mathrm{~d}, 3 \mathrm{H}, 6.6 \mathrm{~Hz})$ & 20.9 \\
\hline
\end{tabular}

The ${ }^{1} \mathrm{H}-\mathrm{NMR}$ spectrum (Figure S5) shows the signals of the methynic hydrogens $\mathrm{H}-6$ ( $\delta: 6.5, \mathrm{~d}, 1 \mathrm{H}, \mathrm{J}: 8.3 \mathrm{~Hz}), \mathrm{H}-7$ ( $\delta: 6.3, \mathrm{~d}, 1 \mathrm{H}, \mathrm{J}=8.3 \mathrm{~Hz}), \mathrm{H}-22$, and $\mathrm{H}-23(\delta: 5.1-5.2, \mathrm{~m}, 1 \mathrm{H})$.

Brassicasterol (17) from fraction 3 of third column 3 was analyzes by the ${ }^{13} \mathrm{C}-\mathrm{NMR}$ and 28 carbons were found in the spectrum that matched the structure identified by GC-MS, at the retention time of 88.4 minutes, with a similarity index of $75 \%$ as shown in Table 1. The compound was identified in the fraction extracted in ethyl acetate from the mycelium, however, it was isolated from the fraction in hexane, indicating that not all compounds were extracted by the liquid-liquid partition. The GC-MS data were compared with the NMR data.

Of the 28 signals observed in the ${ }^{13} \mathrm{C}-\mathrm{NMR}$ spectrum (Figure S3), the following are highlighted: the signal with a shift in $\delta 72.2 \mathrm{ppm}$ referring to carbinolic carbon (C-3); 4 signals referred to alkene: $141.1 \mathrm{ppm}$ to the quaternary carbon (C-5), three referring to the methynic carbons in $\delta 122.1$ (C-6), 132.1 (C-22), and $136.2 \mathrm{ppm}(\mathrm{C}-23)$.

With DEPT-135 (Figure S4) it was possible to verify the absence of carbons 10 and 13 which are quaternary, with displacements in $\delta 36.9$ and $42.6 \mathrm{ppm}$ respectively. The presence of 6 carbons methylic in $\delta 12.4$ (C-18), 21.4 (C-19), 17.9 (C-21), 19.9 (C- 26), 19.7 (C-27), and 20.3 ppm (C-28).

It was also possible with DEPT-135 the identification of methylene carbons, with displacements in $\delta 31.9$ (C-1), 37.6 (C-2), 42.5 (C-4), 29.9 (C-7), 21.3 (C-11), 40.0 (C-12), 28.8 (C-15), and $24.6 \mathrm{ppm}$ (C-16). Additionally, methynic carbons in $\delta 32.2$ (C-8), 50.5 (C-9), 56.3 (C-14), 57.2 (C-17), 40.5 (C-20), 43.1 (C-24), and 33.4 ppm (C-25). The data obtained 
by ${ }^{13} \mathrm{C}-\mathrm{NMR}$ were compared with data from Sun et al. [24] (Table 3), which confirmed the structure of the steroid Brassicasterol (17).

Table 3. ${ }^{1} \mathrm{H}$ and ${ }^{13} \mathrm{C}$ NMR data of brassicasterol (17).

\begin{tabular}{|c|c|c|c|c|c|}
\hline \multicolumn{4}{|c|}{ Experimental Data } & \multicolumn{2}{|c|}{ Literature [24] } \\
\hline Carbon & $\begin{array}{c}{ }^{1} \mathrm{H} \mathrm{NMR} \\
\left(400 \mathrm{MHz}, \mathrm{CDCl}_{3}\right) \\
\delta(\mathrm{m}, \text { Integral }, J)\end{array}$ & $\begin{array}{c}{ }^{13} \mathrm{C} \mathrm{NMR} \\
\left(100 \mathrm{MHz}, \mathrm{CDCl}_{3}\right) \\
\delta\end{array}$ & DEPT-135 & $\begin{array}{c}{ }^{1} \mathrm{H} \text { NMR } \\
\left(400 \mathrm{MHz}, \mathrm{CDCl}_{3}\right) \\
\delta(\mathrm{m}, \text { Integral, } J)\end{array}$ & $\begin{array}{c}{ }^{13} \mathrm{C} \mathrm{NMR} \\
\left(100 \mathrm{MHz}, \mathrm{CDCl}_{3}\right) \\
\delta\end{array}$ \\
\hline 1 & & 31.9 & $\mathrm{CH}_{2}$ & & 31.8 \\
\hline 2 & & 37.6 & $\mathrm{CH}_{2}$ & & 37.4 \\
\hline 3 & $3.48-3.55(\mathrm{~m}, 1 \mathrm{H})$ & 72.2 & $\mathrm{CH}$ & $3.55(\mathrm{~m}, 1 \mathrm{H})$ & 72.0 \\
\hline 4 & & 42.5 & $\mathrm{CH}_{2}$ & & 42.4 \\
\hline 5 & & 141.1 & $\mathrm{C}^{2}$ & & 140.9 \\
\hline 6 & $5.33-5.35(\mathrm{~m}, 1 \mathrm{H})$ & 122.1 & $\mathrm{CH}$ & $5.34(\mathrm{~m}, 1 \mathrm{H})$ & 121.9 \\
\hline 7 & & 29.9 & $\mathrm{CH}_{2}$ & & 29.9 \\
\hline 8 & & 32.2 & $\mathrm{CH}$ & & 32.1 \\
\hline 9 & & 50.5 & $\mathrm{CH}$ & & 50.3 \\
\hline 10 & & 36.9 & $\mathrm{C}$ & & 36.7 \\
\hline 11 & & 21.3 & $\mathrm{CH}_{2}$ & & 21.2 \\
\hline 12 & & 40.0 & $\mathrm{CH}_{2}$ & & 39.8 \\
\hline 13 & & 42.6 & $\mathrm{C}$ & & 42.5 \\
\hline 14 & & 56.3 & $\mathrm{CH}$ & & 56.2 \\
\hline 15 & & 28.8 & $\mathrm{CH}_{2}$ & & 28.7 \\
\hline 16 & & 24.6 & $\mathrm{CH}_{2}$ & & 24.4 \\
\hline 17 & & 57.2 & $\mathrm{CH}$ & & 57.0 \\
\hline 18 & & 12.4 & $\mathrm{CH}_{3}$ & & 12.2 \\
\hline 19 & & 21.4 & $\mathrm{CH}_{3}$ & & 21.1 \\
\hline 20 & & 40.5 & $\mathrm{CH}$ & & 40.3 \\
\hline 21 & $0.9(\mathrm{~d}, 3 \mathrm{H}, 6.8 \mathrm{~Hz})$ & 17.9 & $\mathrm{CH}_{3}$ & $0.91(\mathrm{~d}, 3 \mathrm{H} .6 .8 \mathrm{~Hz})$ & 17.8 \\
\hline 22 & $5.17-5.19(\mathrm{~m}, 1 \mathrm{H})$ & 132.1 & $\mathrm{CH}$ & $5.18(\mathrm{~m}, 1 \mathrm{H})$ & 131.9 \\
\hline 23 & $5.17-5.19(\mathrm{~m}, 1 \mathrm{H})$ & 136.2 & $\mathrm{CH}$ & & 136.0 \\
\hline 24 & & 43.1 & $\mathrm{CH}$ & & 43.0 \\
\hline 25 & & 33.4 & $\mathrm{CH}$ & & 33.3 \\
\hline 26 & $0.94(\mathrm{~d}, 3 \mathrm{H}, 6.5 \mathrm{~Hz})$ & 20.0 & $\mathrm{CH}_{3}$ & $0.83(\mathrm{~d}, 3 \mathrm{H}, 6.5 \mathrm{~Hz})$ & 19.8 \\
\hline 27 & $0.94(\mathrm{~d}, 3 \mathrm{H}, 6.5 \mathrm{~Hz})$ & 19.7 & $\mathrm{CH}_{3}$ & $0.82(\mathrm{~d}, 3 \mathrm{H}, 6.5 \mathrm{~Hz})$ & 19.6 \\
\hline 28 & $0.72(\mathrm{~s}, 3 \mathrm{H})$ & 20.3 & $\mathrm{CH}_{3}$ & $0.69(\mathrm{~s}, 3 \mathrm{H})$ & 20.1 \\
\hline
\end{tabular}

The ${ }^{1} \mathrm{H}-\mathrm{NMR}$ spectrum (Figure S2) shows the signal of the methynic hydrogen of

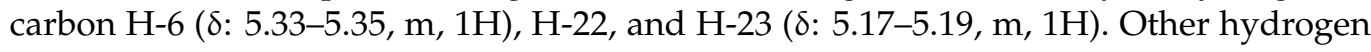
signals in the spectrum have been identified and compared with the literature, such as methynic hydrogen of carbon $\mathrm{H}-3(\delta: 3.48-3.55, \mathrm{~m}, 1 \mathrm{H})$, which is hydrogen of carbinolic carbon. There are also the methylic hydrogens $\mathrm{H}-21(\delta: 0.9, \mathrm{~d}, 3 \mathrm{H}, \mathrm{J}: 6.8 \mathrm{~Hz}), \mathrm{H}-26$, and H-27 ( $8: 0.94, d, 3 \mathrm{H}, J: 6.5 \mathrm{~Hz})$.

\subsection{Antibacterial Activity}

The antibacterial activity was evaluated to test the "Minimum inhibitory concentration" (MIC), that is, the minimum concentration capable of inhibiting bacterial growth. The results are shown in Table 4 . The results that are considered present good activity against bacteria are those whose minimum inhibitory concentrations are close to $100 \mu \mathrm{g} \mathrm{mL}^{-1}$, whereas concentrations between 200 and $500 \mu \mathrm{g} \mathrm{mL}^{-1}$ are considered to be moderate activity [25]. 
Table 4. Minimum inhibitory concentration of C. brachiata extracts against oral bacteria.

\begin{tabular}{|c|c|c|c|c|c|}
\hline & \multirow[b]{2}{*}{ Microorganisms } & \multicolumn{4}{|c|}{ Minimum Inhibitory Concentration (MIC $-\mu \mathrm{g} \mathrm{mL}^{-1}$ ) } \\
\hline & & A & B & $\mathrm{C}$ & $\begin{array}{l}\text { Positive } \\
\text { Control * }\end{array}$ \\
\hline \multirow{4}{*}{$\begin{array}{l}\text { Aerobic } \\
\text { bacteria }\end{array}$} & S. mutans ${ }^{1}$ & $>400$ & $>400$ & $>400$ & 0.92 \\
\hline & S. mitis ${ }^{1}$ & $>400$ & 400 & 200 & 3.68 \\
\hline & S. sanguinis ${ }^{1}$ & $>400$ & 200 & 400 & 0.92 \\
\hline & A. actinomycetemcomitans ${ }^{2}$ & $>400$ & 400 & $>400$ & 0.46 \\
\hline \multirow{3}{*}{$\begin{array}{c}\text { Anaerobic } \\
\text { bacteria }\end{array}$} & P. gingivalis 2 & 400 & 200 & 400 & 3.68 \\
\hline & F. nucleatum ${ }^{2}$ & $>400$ & 400 & $>400$ & 1.84 \\
\hline & A. naeslundii ${ }^{1}$ & 200 & 100 & 400 & 1.84 \\
\hline
\end{tabular}

Note: A: ethyl acetate from the growth broth; B: ethyl acetate from mycelia; C: hexane from mycelia. ${ }^{1}$ Gram-positive bacteria; ${ }^{2}$ Gram-negative bacteria * Positive control: chlorhexidine dihydrochloride. Bacteria to control of the technique by protocol M11-A7 CLSI [16]: $B$. fragilis (MIC $\left.=0.7 \mu \mathrm{g} \mathrm{mL}{ }^{-1}\right)$ and B. thetaiotaomicron (MIC $=1.5 \mu \mathrm{g} \mathrm{mL}-1$ ).

Regarding aerobic bacteria, the values found for antibacterial activity are considered moderate for the hexane extract of mycelium against S.mitis and S. sanguinis; for the ethyl acetate extract of mycelium against $S$. mitis, S. sanguinis, and A. actinomycetemcomitans. The ethyl acetate extract from the broth showed no activity within the range of the concentrations tested ( 0.195 to $400 \mu \mathrm{g} \mathrm{mL}^{-1}$ ).

Regarding the anaerobic bacteria, the results showed that the ethyl acetate extract of the mycelium inhibited the growth of all tested bacteria with promising activity to A. naeslundii $\left(100 \mu \mathrm{g} \mathrm{mL}^{-1}\right)$. The hexane extract of the mycelium and ethyl acetate extract from the broth showed moderate activity against the bacteria $P$. gingivalis and A. naeslundii with MIC values from 200 to $400 \mu \mathrm{g} \mathrm{mL} \mathrm{m}^{-1}$.

Previous work has already reported the antibacterial activity of the metabolites of the fungus Cercospora sp. against the bacteria Bacillus subtilis and Staphylococcus aureus [8]. However, the results were given in a zone of inhibition of halo, presenting values of $15.0 \pm 0.3$ and $25.0 \pm 0.4 \mathrm{~mm}$, respectively. This antibacterial activity observed, even in a qualitative way, corroborates with the data of this work, in which the extracts of the fungus Cercospora sp. inhibited the growth of different oral bacteria with concentrations between 100 and $400 \mu \mathrm{g} \mathrm{mL}^{-1}$. Therefore, the antibacterial activity of the metabolites of this fungus is demonstrated.

Fatty acids and steroids were one of the main classes of metabolites found in the extracts, and the results found may be related to the presence of these constituents.

The antibacterial properties of fatty acids are well known, the intensity of activity can be influenced by the length and shape of the chain size and also by the presence or absence of unsaturations. Hydrophobic and hydrophilic interactions of fatty acids with the bacterial cell membrane generate structural changes in the bacterial cell. This process can affect the energy production, inhibit enzymatic activity, impair nutrient absorption, generate degradation products (auto-oxidation and peroxidation), or promote lysis of the cell membrane contributing to growth inhibition or death of the bacterium [26].

Steroids were another class of compounds identified and isolated from the extracts of the fungus Cercospora. Steroids can also be considered to contribute to the antimicrobial action of extracts. Other works have already demonstrated the potential of these compounds against different Gram-negative and Gram-positive bacteria [27-30]. They have an action similar to fatty acids on cell membranes, as they adhere to the lipid layers of the membranes, favoring the passage of nutrients and cell lysis [31]. Thus, fatty acids and steroids can be the bioactive compounds responsible for the activity of the extracts. 


\section{Conclusions}

The chemistry of natural products continues to be an important component in science because it is in contact with the various studies related to biota, fauna, and flora. The fungi are part of this biological system and their chemical and biological analyses bring important contributions to clarify the chemical composition of the compounds produced by these fungi and correlations of chemical profiles between genera and species can be obtained.

Among the compounds identified, fatty acids, esters, and steroids were found, which have structural functions in the cell membrane, so it is reasonable that they are found in fungus extracts.

In this work, the antibacterial activity of Cercospora brachiata extracts was evaluated. It was observed that the extracts from extractions with ethyl acetate presented promising values against anaerobic bacteria of the oral cavity.

Supplementary Materials: The following are available online at https: / www.mdpi.com/article/ 10.3390/jof7090680/s1, Figure S1: Structure of the isolated molecules of C. brachiata, Figure S2: ${ }^{1} \mathrm{H}$ NMR spectra $\left(400 \mathrm{MHz}, \mathrm{CDCl}_{3}\right.$ ) of Brassicasterol (17), Figure S3: ${ }^{13} \mathrm{C}$ NMR spectra $\left(100 \mathrm{MHz}, \mathrm{CDCl}_{3}\right)$ of Brassicasterol (17), Figure S4: DEPT-135 NMR spectra (100 MHz, $\mathrm{CDCl}_{3}$ ) of Brassicasterol (17), Figure S5: ${ }^{1} \mathrm{H}$ NMR spectra $\left(400 \mathrm{MHz}, \mathrm{CDCl}_{3}\right.$ ) of Ergosta-6,22-dien-3 $\beta, 5 \alpha, 8 \alpha$-triol (31), Figure S6: ${ }^{13} \mathrm{C}$ NMR spectra (100 MHz, $\mathrm{CDCl}_{3}$ ) of Ergosta-6,22-dien-3 $\beta, 5 \alpha, 8 \alpha$-triol (31), Figure S7: DEPT-135 NMR spectra $\left(100 \mathrm{MHz}, \mathrm{CDCl}_{3}\right)$ of Ergosta-6,22-dien-3 $\beta, 5 \alpha, 8 \alpha$-triol (31).

Author Contributions: Conceptualization, B.S.V. and R.M.F.S.; methodology, J.K.R.P.F., M.B.S. and N.A.d.S.; software, J.K.R.P.F. and R.M.F.S.; validation, J.K.R.P.F., M.B.S., N.A.d.S., B.S.V., L.C.S.C. and R.M.F.S.; formal analysis, J.K.R.P.F. and N.A.d.S.; investigation, J.K.R.P.F., M.B.S. and N.A.d.S.; resources, R.M.F.S., B.S.V., R.A.A.M. and A.d.O.; data curation, J.K.R.P.F., M.B.S. and N.A.d.S.; writing-original draft preparation, J.K.R.P.F., R.A.A.M. and R.M.F.S.; writing-review and editing, J.K.R.P.F., B.S.V., C.H.G.M., L.C.S.C., R.A.A.M., A.d.O. and R.M.F.S.; visualization, J.K.R.P.F., N.A.d.S., M.B.S., B.S.V., C.H.G.M., L.C.S.C., R.A.A.M., A.d.O. and R.M.F.S.; supervision, B.S.V., C.H.G.M., L.C.S.C., R.A.A.M., A.d.O. and R.M.F.S.; project administration, R.M.F.S.; funding acquisition, R.M.F.S., R.A.A.M. and A.d.O. All authors have read and agreed to the published version of the manuscript.

Funding: This research was funded by (1) FAPEMIG: grant numbers APQ-01612-18 and APQ-0234218, awarded to A.d.O. and R.M.F.S., respectively. (2) CNPq, 307271/2017-0, awarded to R.A.A.M. (3) This study was financed in part by the Coordination for the Improvement of Higher Education Personnel (CAPES), Finance Code 001.

Institutional Review Board Statement: Not applicable.

Informed Consent Statement: Not applicable.

Acknowledgments: The researchers also acknowledge FAPEMIG, CAPES, and CNPq for scholarships and the Institute of Chemistry of the Federal University of Uberlândia. The authors thank Ricardo Reis Soares for GC-MS equipment.

Conflicts of Interest: The authors declare no conflict of interest.

\section{References}

1. Fontana, D.C.; de Paula, S.; Torres, A.G.; de Souza, V.H.M.; Pascholati, S.F.; Schmidt, D.; Neto, D.D. Endophytic fungi: Biological control and induced resistance to phytopathogens and abiotic stresses. Pathogens 2021, 10, 570. [CrossRef]

2. Dyakov, Y.T.; Zinovyeva, S.V. Chapter 5-Horizontal pathosystem: Parasite attack factors. In Comprehensive and Molecular Phytopathology; Dyakov, Y.T., Dzhavakhiya, V.G., Korpela, T., Eds.; Elsevier: Amsterdam, The Netherlands, 2007 ; pp. 139-159.

3. Firáková, S.; Šturdíková, M.; Múčková, M. Bioactive secondary metabolites produced by microorganisms associated with plants. Biologia 2007, 62, 251-257. [CrossRef]

4. Sharma, P.; Jha, A.B.; Dubey, R.S.; Pessarakli, M. Reactive oxygen species, oxidative damage, and antioxidative defense mechanism in plants under stressful conditions. J. Bot. 2012, 2012, 217037. [CrossRef]

5. Daub, M.E.; Herrero, S.; Chung, K.R. Reactive oxygen species in plant pathogenesis: The role of perylenequinone photosensitizers. Antioxid. Redox. Signal. 2013, 19, 970-989. [CrossRef] 
6. Santos, F.d.S.; Souza, P.E.d.; Pozza, E.A.; Miranda, J.C.; Barreto, S.S.; Theodoro, V.C. Progress of brown eye spot (Cercospora coffeicola Berkeley \& Cooke) in coffee trees in organic and conventional systems. Summa Phytopathol. 2008, 34, 48-54. [CrossRef]

7. De Lima, L.M.; Pozza, E.A.; Santos, F.D.S. Relationship between incidence of brown eye spot of coffee cherries and the chemical composition of coffee beans. J. Phytopathol. 2012, 160, 209-211. [CrossRef]

8. Hema, P.; Murali, M.; Thriveni, M.C.; Prathibha, M.; Jayaramu, S.C.; Amruthesh, K.N. Phytochemical analysis and antibacterial activity of endophytic fungi isolated from Basella rubra 1.-A medicinal plant. J. Pure Appl. Microbiol. 2015, 9, $2971-2978$.

9. Kumar, P.S. Oral microbiota and systemic disease. Anaerobe 2013, 24, 90-93. [CrossRef]

10. Adams, R.P. Identification of Essential Oil Components by Gas Chromatography/Quadrupole Mass Spectroscopy, 4th ed.; Allured Bussiness Media: Carol Stream, IL, USA, 2007; p. 804.

11. Vieira, B.S.; da Silva, N.A.; Firmino, A.L.; Siquieroli, A.C.S. Cercospora brachiata on slender amaranth (Amaranthus viridis) in Brazil. Australas. Plant. Dis. Notes 2019, 14, 6. [CrossRef]

12. Fargues, J.; Smits, N.; Vidal, C.; Vey, A.; Vega, F.; Mercadier, G.; Quimby, P. Effect of liquid culture media on morphology, growth, propagule production, and pathogenic activity of the Hyphomycete, Metarhizium flavoviride. Mycopathologia 2002, 154, 127-138. [CrossRef] [PubMed]

13. Duarte, M.d.L.R.; Archer, S.A. In vitro toxin production by Fusarium solani f. sp. piperis. Fitopatol. Bras. 2003, 28, 229-235. [CrossRef]

14. Intaraudom, C.; Bunbamrung, N.; Dramae, A.; Boonyuen, N.; Komwijit, S.; Rachtawee, P.; Pittayakhajonwut, P. Acremonidins F-H and acremoxanthones F-G, antimicrobial substances from the insect fungus Verticillium sp. BCC33181. Tetrahedron 2016, 72, 1415-1421. [CrossRef]

15. CLSI. Methods for Antimicrobial Susceptibility Testing of Anaerobic Bacteria, 8th ed.; Approved Standard; CLSI document M11-A8; Clinical Laborartory Standards Institute: Wayne, PA, USA, 2012. Available online: https://clsi.org/media/1468/m11a8_sample. pdf (accessed on 18 August 2021).

16. CLSI. Methods for Dilution Antimicrobial Susceptibility Tests for Bacteria That Grow Aerobically, 10th ed.; Approved Standard; CLSI document M07-A10; Clinical Laboratory Standards Institute: Wayne, PA, USA, 2015. Available online: https://clsi.org/media/16 32/m07a10_sample.pdf (accessed on 18 August 2021).

17. Kaushik, N.; Díaz, C.E.; Chhipa, H.; Fernando Julio, L.; Fe Andrés, M.; González-Coloma, A. Chemical composition of an aphid antifeedant extract from an endophytic fungus, Trichoderma sp. Efi671. Microorganisms 2020, 8, 420. [CrossRef]

18. Mohamed, H.; El-Shanawany, A.R.; Shah, A.M.; Nazir, Y.; Naz, T.; Ullah, S.; Mustafa, K.; Song, Y. Comparative analysis of different isolated oleaginous Mucoromycota fungi for their $\gamma$-linolenic acid and carotenoid production. BioMed Res. Int. 2020, 2020, 3621543. [CrossRef]

19. Lang, R.; Mattner, J. The role of lipids in host microbe interactions. Front. Biosci. 2017, 22, 1581-1598. [CrossRef]

20. Kennedy, M.J.; Reader, S.L.; Davies, R.J. Fatty acid production characteristics of fungi with particular emphasis on gamma linolenic acid production. Biotechnol. Bioeng. 1993, 42, 625-634. [CrossRef] [PubMed]

21. Blacklock, B.J.; Scheffler, B.E.; Shepard, M.R.; Jayasuriya, N.; Minto, R.E. Functional diversity in fungal fatty acid synthesis: The first acetylenase from the pacific golden chanterelle, Cantharellus formosus. J. Biol. Chem. 2010, 285, 28442-28449. [CrossRef] [PubMed]

22. Dewick, P.M. The mevalonate and methylerythriol phosphate pathways: Terpenoids and steroids. In Medicinal Natural Products: A Biosynthetic Approach; Dewick, P.M., Ed.; John Wiley \& Sons, LTD.: Hoboken, NJ, USA, 2009; p. 507.

23. Rivera, A.; Benavides, O.L.; Rios-Motta, J. (22E)-Ergosta-6,22-diene- $3 \beta, 5 \alpha, 8 \alpha$-triol: A new polyhydroxysterol isolated from Lentinus edodes (Shiitake). Nat. Prod. Res. 2009, 23, 293-300. [CrossRef]

24. Sun, Y.; Lin, Y.; Cao, X.; Xiang, L.; Qi, J. Sterols from mytilidae show anti-aging and neuroprotective effects via anti-oxidative activity. Int. J. Mol. Sci. 2014, 15, 21660-21673. [CrossRef] [PubMed]

25. Holetz, F.B.; Pessini, G.L.; Sanches, N.R.; Cortez, D.A.G.; Nakamura, C.V.; Filho, B.P.D. Screening of some plants used in the Brazilian folk medicine for the treatment of infectious diseases. Mem. Inst. Oswaldo Cruz 2002, 97, 1027-1031. [CrossRef] [PubMed]

26. Desbois, A.P.; Smith, V.J. Antibacterial free fatty acids: Activities, mechanisms of action and biotechnological potential. Appl. Microbiol. Biotechnol. 2010, 85, 1629-1642. [CrossRef]

27. Ralambondrahety, R.; Couzinet-Mossion, A.; Rabesaotra, V.; Andriambeloson, O.; Barnathan, G.; Rakotovao, M.; Wielgosz-Collin, G. Antibacterial activity of steroids isolated from the madagascar marine sponge biemna laboutei: $\Delta 7$ steroids as new potential agents against pathogenic bacteria. Nat. Prod. J. 2021, 11, 57-62. [CrossRef]

28. Azizi, R.; Motallebi Moghanjoughi, A.A.; Nazemi, M.; Sharif Ruhani, M.; Afshar Nasab, M. Isolation and identification of antibacterial steroid compounds from Ulva fasciata in the Persian Gulf. Iran. J. Fish. Sci. 2020, 19, 2384-2393. [CrossRef]

29. Dogan, A.; Otlu, S.; Çelebi, O.; Kiliçle, P.A.; Saglam, A.G.; Dogan, A.N.C.; Mutlu, N. An investigation of antibacterial effects of steroids. Turk. J. Vet. Anim. Sci. 2017, 41, 302-305. [CrossRef]

30. Zhu, F.; Li, J.; Xie, W.; Wang, C.; Liu, Y. Identification and antibacterial activity of two steroids secreted by the fungus beetle Xylographus bostrichoides (dufour, 1843). Bangladesh J. Bot. 2017, 46, 1171-1176.

31. Savage, P.B.; Li, C.; Taotafa, U.; Ding, B.; Guan, Q. Antibacterial properties of cationic steroid antibiotics. FEMS Microbiol. Lett. 2002, 1, 1-7. [CrossRef] 